\title{
ANTIGENIC CHARACTERS OF CAMP-FACTORS PRODUCED BY DIFFERENT STRAINS OF STREPTOCOCCUS AGAL ACTIAB
}

\section{B. SKALKA}

Department of Epizootiology and Microbiology, University of Veterinary Science, 61242 Brno

Received February 1, 1985

\begin{abstract}
$S k$ a 1 a B.: Antigenic Characters of CAMP-factors Produced by Different Strains of Streptococcus agalactiae. Acta Vet. Brno, 55, 1986: 183-190.

Antigenic relations of CAYP-factors produced by different strains of Streptococcus agalictiae were studied within the framework of this species. Prepurified forms of CAMP-factors produced by the serotypes Ia, Ib, IC, II, III $X$, and $R$ were used to prepare antisera by repeated intravenous injections into rabbits. Two techniques of precipitation were used for serological tests, namely the agar immunodiffusion with prepurified CAYP-factors as antigens and the modified Elek-Ouchterlony test employing the native form of this exosubstance. CAYP-Factors gave positive precipitation with homologous and heterologous rabbit antisera. Three precipitation IInes were formed in the cases of homogeneity, one of them beeing very conspicuos, and two lines only originated when CAMP-factor and antiserum were heterologus. As a rule these two lines were faint. Our results proved existence of both specific and comen antigenic fractions in CAMP-factors. The Elek-Ouchterlony test was carried out for Investigation of $300 \mathrm{~S}$. agalactiae strains, based on serotyping of their CAMP-factors. All strains were isolated by us from clinical waterials, and they were tested with rabbit antisera to CAMP-factors of the serotype strains. Among 150 strains from humans, CAMP-factors reacted mostly in the same way as those of strains Ic and III, among 150 strains from bovine udders, in the same way as CAMP-factors of strains $X$ and $R$.

native and prepurified CAMP-factors, serotypes of Streptococcus agalactiae, CAMP-factor antisera, agar immunodiffusion, ElekOuchterlony test.
\end{abstract}

The exosubstance of $S$. agalactiae, called CAMP-factor ( $P$ u 1 s f o r d 1954) 1s characterized by 1 ts synergistic hemolytic reaction with staphylococcal beta toxin (C h r 1 \& t 1 e et al. 1944), or with corynebacterial phospholipase D (F r a e r 1964; S k a 1 k a et al. 1979b) on sheep or bovine erythrocytes. Th1s synergistic action was explained efther by lipase activity of CAMP-factor ( $\mathrm{K}$ a $\mathrm{r} \mathrm{C}$ h $\mathrm{u} d \mathrm{r}$ y 1978) or by 1 ts binding to ceramide liberated by the prior action of staphylococcal sphingomyelinase on sheep erythrocytes (B $\mathrm{e} n-$ he 1 e $r$ et al. 1979). Evidently, CAMP-factor is produced by all $S$. agalactiae strains, even during their growth in the L-phase ( $\mathrm{s}$ a $1 \mathrm{k}$ a et al. 1979b; Ph $1111 \mathrm{ps}$ et al. 1980; F $10 \mathrm{res}$ and Fer r 1 e 1 1983). Antigenicity of CAMP-factor was described (B $r$ o $n$ et al. 1974; $s k$ a $1 k$ a et al. 1980; $F 1 \circ r \in s$ and $F \in r$ r $1 \in T 1$ 1983), as well as 1 ts toxic and even lethal effect for rabbit and nouse ( $k a 1 k$ and $S=01$ a 1981). The CAMP-factor producing streptococcl belong to Lancefleld group B according to the antigen present in their cells ( $L$ a $c$ e f 1 e 1 d 1933), nevertheless, a serological subdivision to types 18 possible within this group (L a $n$ c $f$ f 1 e 1 d 1934; P t t 1 s o n et al. 1955; W $11 k 1 \mathrm{n}$ \& $\mathrm{n}$ a nd Mo o d y 1969;

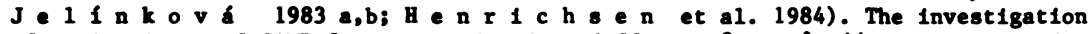
of antigenicity of CAMP-factors produced by different $S$. agalactiae strains, and their diagnostical employment was the topic of the present study. 
Materials and Methode

$M \bullet \mathrm{d} 1$ a

Brain heart Infusion CM225 and Brain heart Infusion agar CM375 (Oxo1d Ltd.) were used. For blood agar preparation, the solid base was suppleaented by $5 \mathrm{Z}$ washed sheep erythrocytes and $2.5 \mathrm{mg} \mathrm{ml}^{-1} \mathrm{M}_{8} \mathrm{SO}_{4}$.

Bacter 1 a 1 s t ra 1 ns

S. agalactiae (Str B) from the Czechoslovak National Collection of Type Cultures (CNCTC) were used, nanely $8 / 70$ for type Ia, 9/70 for type Ib, 5/70 for type Ic, 3/70 for type II, $4 / 70$ for type III, $24 / 60$ for type $X, 25 / 60$ for type $R$, and $8 / 66$ for the strain posessing exclusively the group antigen ( $S \circ$ u $r k 1981$ ) and referred further as B.

Additionally enployed streptococcal strains were S. pyogenes Str A $3 / 55$ and $2 / 56$, S. zooepidemicus Str C $4 / 49$, S. equisimilis Str C $7 / 49, S$. dysgalactiae Str C $12 / 77$, S. equi Str C $3 / 78$, and further Str E $42 / 59$, Str F 4/65, Str P 19/55, Str P 21/55, Str U 1/70, Str V 1/75, all from CNCTC.

S. aureus CCM 6188 served both for routine CAMP-test and for preparing prepurified form of 1ts beta toxin. The strain of Corynebacterlum pseudotuberculosis CNCTC Cor 39/70 was used for hemolytic synergisa test.

Horeover, $300 \mathrm{~S}$. agalactial strains were examined, 150 of them 1solated from humans and 150 from bovine udders.

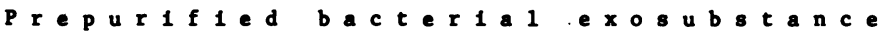

CAMP-factors and staphylococcal beta toxin were prepared by aceton precipitation, exanined fro their activity which is expressed in activity units (AU), and stored as described earlier ( $k$ a $1 \mathrm{k}$ a et al. 1979a). The term prepurified 18 used in order to distinguish this from the native and purified froms.

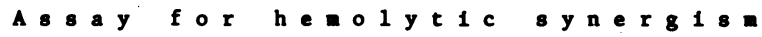

All strains of streptococcl were exanined fro their hemolytic synergism with staphylococcal beta toxin and corynebacterial phospholipase D by a modified CAMPtest as described earlier ( $k$ a $1 k$ a et al. 1980). Type strains of $S$. agalactiae and their CAMP-factors were also verified on blood agar with a staphylococcal beta toxin content of $7.5 \mathrm{AU}^{-1}$.

CA M - f a c t r a n t 1 s e a

CAMP-factor antisera were prepared by repeated intravenous infection of prepurified exosubstance into rabbits according a schema described earlier $S \mathrm{k} a \mathrm{k}$ a et al. 1980). CAMP-factors of $S$. agalactiae type culture were used. The antisera gained were inactivated at $56^{\circ} \mathrm{C}$ for $30 \mathrm{~min}$ and absorbed with heat -killed pellets of homologous and heterologous S. agalactiae type strains. Then the antisera were centrifuged and their supernatants were collected and used.

A comercial antiserum for serological identification of group B streptococc1, delivered by OSOL (Prague), was used for checking.

Se r 01081 c a 1 a s s a y 8 for CAMP-f a c t o r s

Serological assays were performed both with prepurified CAMP-factors and with their native forms, produced on agar media by the growth of $S$. ugalactial strains. Both forms of CAMP-factors were examined with homologous and heterologous sera.

In order to examine prepurified CAMP-factors, double agar immodiffussion was performed. Wells of $1 \mathrm{~cm}$ diameter were cut 1 the medium at a distance of $1 \mathrm{~cm}$ each from the other. The wells were filled with the antisera of prepurified CAMP-factors under study. The dish was kept for $48 \mathrm{~h}$ at $37^{\circ} \mathrm{C}$, and after this time the result was read.

$A$ modification ( $\mathrm{k} a \mathrm{l}$ a and $\mathrm{S}$ a $8 \mathrm{t} \mathrm{v}$ a 1985) of the technique described by $E 1 \in k$ (1948) and 0 u c h t e $10 \mathrm{n}$ y (1948) was performed for native CAMP-factors. It was convenient both for one strain tested with all antisera, and for four strains tested simultaneously against one serum. In the first case, the streptococcal strain was streaked on agar medium in the middle of the Petri dish and the dish was incubated at $37^{\circ} \mathrm{C}$ for $24 \mathrm{~h}$. Wells of $1 \mathrm{~cm}$ dianeter were cut in the mediun at a distance of $1 \mathrm{~cm}$ from the culture line. The wells were filled with the CAMP-factor antisera. The dish was kept for an 
additional $48 \mathrm{~h}$ at $37^{\circ} \mathrm{C}$, and after this time the result was read. When testing strains against one antiserum, four strains were streaked around one well. The rest of the proceeding remained unchanged.

\section{Results}

The production of CAMP-factor by different $S$. agalactiae serotype strains was not of equal intensity. Differences were to be observed both with the modified CAMP-test using $S$. aureus and C.pseudotuberculosis and with streptococcal strains growing on blood agar with staphylococcal bet:a toxin (Fig. 1). A similarly different

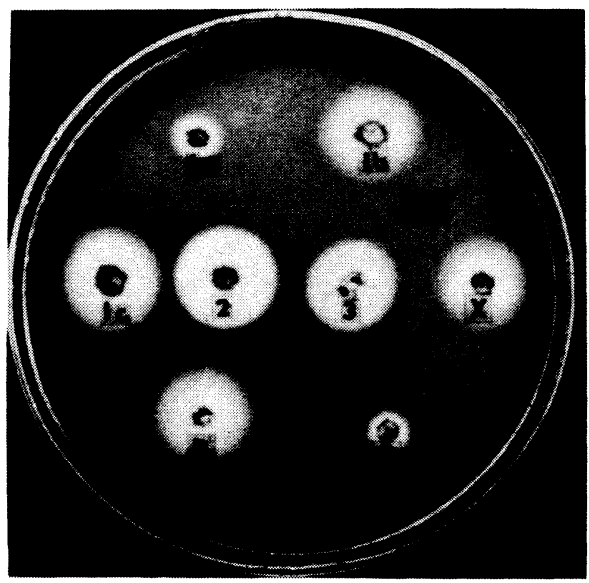

Fig. 1

Synergistic hemolytic effects of $S$. agalactiae serotype strains on nutrient medium (BT) contalning $5 \%$ washed sheep erythrocytes and staphylococcal beta toxin $7.5 \mathrm{AU} \mathrm{ml}^{-1}$. The culture spots are marked according to the serotypes, with exception of II $(=2)$ and III $(=3)$.

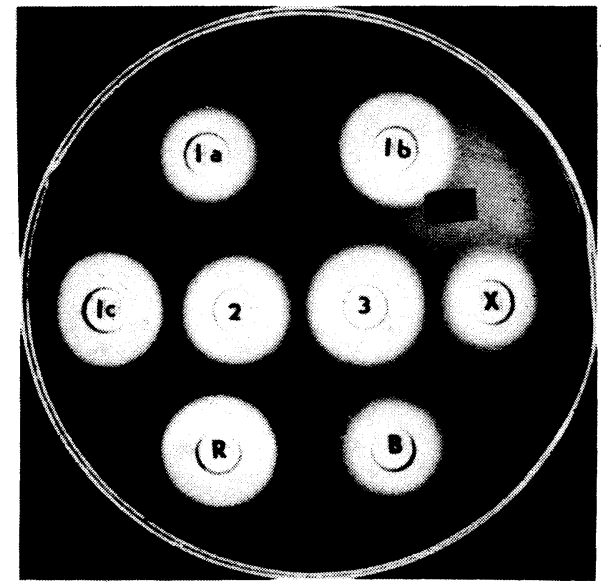

F18. 2

Prepurified CAMP-factors of $S$. agalactiae serotype strains are placed in the wells which were cut into the same medium as on Fig. 1. 
intensity of CAMP-factor production was also detected in $S$. agalactiae strains from clinical material. However, a prepurified CAMP-factor was to be obtained of every serotype strain, and the differences occuring in its native form could be reduced by convenient adjustment (Fig. 2).

As could be checked by collecting blood samples and examining sera, a sufficient amount of precipitation antibodies was present in sera from hyperimmunized rabbits following the fifteenth dose of antigen. As soon as serum and corresponding antigen reacted satisfactorily, the rabbits were exsanquinated by cardiac puncture. In the case of an insufficient reaction, the animals received further doses of antigen and the checking was repeated.

The reaction between antiserum and homologous antigen resulted in formation of three precipitation lines. This was achieved both with prepurified CAMP-factor in agar immunodiffusion and with its native form in Elek-Ouchterlony (EO) test. The first line was closest to the antigen, thus to the well containing prepurified homologous CAMP-factor or to the streak of the homologous strain, and it was very conspicuous. The second line was located in the middle between antiserum and antigen beeing less marked. The third precipitation line, occasionally missing, was similarly distinct as the second one, and adjoined the well with antiserum. A splitting or confluence of described precipitation lines could be observed in some cases. The second and third precipitation lines originated also in the cases of heterogeneity of antigens and antisera.

The first precipitation line always was intensive between antisera and corresponding CAMP-factors of the S. agalactial strains Ib (Fig. 3), Ic (Fig. 4), $X$ (Fig. 5), and $R$ (Fig. 6), while less marked reactions were observed in homologous

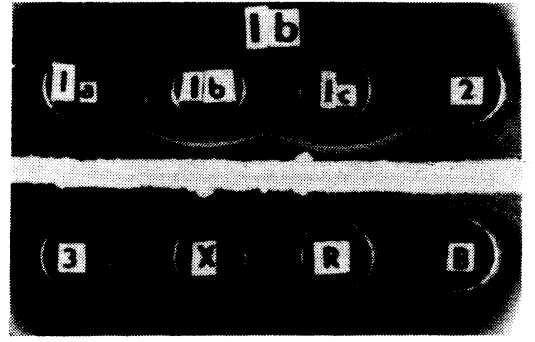

Pin.?

On nutrient agar is a streak (Ib) of $S$. agalactiae serotype Ib. In the wells are CAMP-factor antisera signed according serotype of the producer strain.

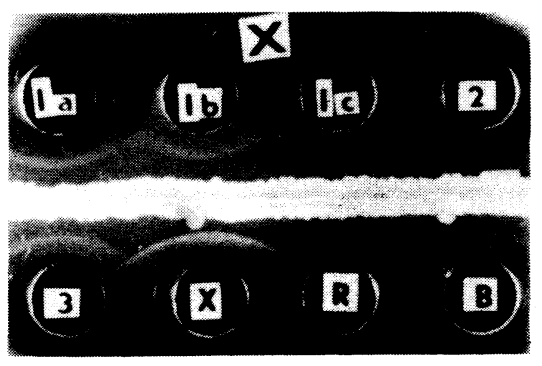

Fig. 5 .

The same reaction as before, but with the strain $S$. agalactiae serotype $X$.
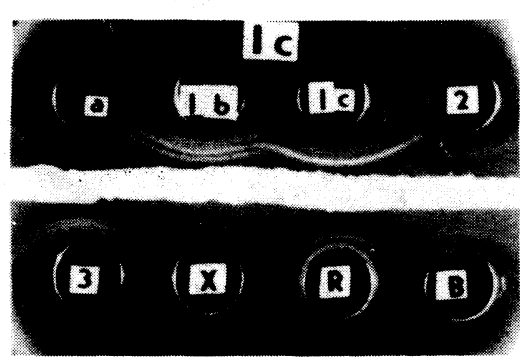

Fig. 4

The same reaction as in Fig. 3, but with the strain S. agalactiae. serotype Ic.

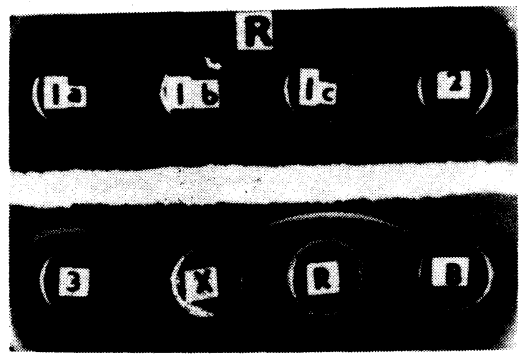

Fig. 6 .

The same reaction as before, but with the strain $S$. agalactiae serotype $R$. 
cases of the rest of CAMP-factors produced by the serotype strains and their corresponding antisera (Fig. 7). As for the first line, the homologous and cross reactions of CAMP-factors produced by the strains Ib and Ic, and their corresponding antisera, were of particular interest. An intensive precipitation line arose both homologous and heterologous reactions, beeing compact in homologous case and splitted in two branches in the heterologous one (Fig. 3 and Fig. 4).

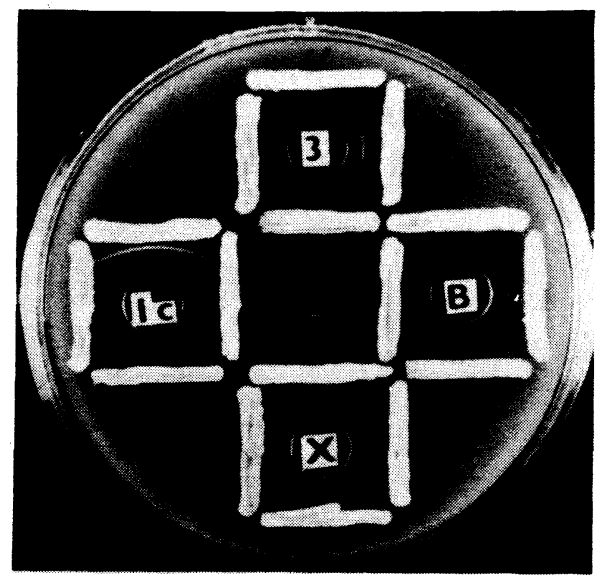

F18. 7

CAMP-factor antisera marked according to the producer strains are in the wells. Streaks of four S. agalactiae strains are around each well. One of the strains 1s homologous and three are heterologous to the CAMP-factor antiserum.

The second precipitation line appeared in any heterologous case both when testing prepared antisera against one strain and when testing one antiserum against four antigens, either native of prepurified. It always joined analogous neighbouring lines assuming so the character of a common line. Similar features though less marked, displayed the third precipitation line.

CAMP-factors of the $150 \mathrm{~S}$. agalactiae strains isolated from humans reacted with

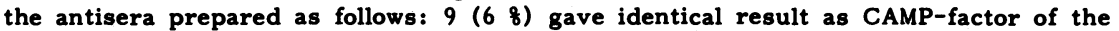
Ia strain, $7(4.68)$ as $\mathrm{Ib}$, and $3(2 \mathrm{8})$ strains in the same way with the antisera of CAMP-factors Ib and Ic. Identically with CAMP-factor of the strain Ic reacted 28 (18.6 8) strains, with CAMP-factor II $15(10$ 8) strains, and with CAMP-factor of the strain III $29(19.3$ \&) strains. Fourteen $(9.3 \%)$ reacted simultaneously with antisera of the CAMP-factors produced by the strain III and R. CAMP-factors of three (2 8$)$ strains were antigenic identical with that of the strain $X$, and two (1.3 8 ) strains displayed a reaction of their exosubstances with antisera of CAMP-factors of the strains $X$ and $R$. The same reaction, as gave the strain $R$, was observed in 17 $(11.38)$ strains, and as the strain $B$ in $4(2.68)$ strains. The rest of $14(9.38)$ strains, as a rule, formed the second and mostly also the third precipitation line while in no case the first one. Consequently these strains could be placed to no described category (Table 1 ).

The typing of 150 agalactiae strains isolated from bovine udders gave following results: CAMP-factors of 2 strains $(1.38)$ reacted like CAMP-factor of the strain Ia, CAMP-factors of $5(3.38)$ strains reacted like that of the strain $\mathrm{Ib}$, and the simultaneous positivity with CAMP-factor antisera Ib and Ic was observed in 2 (1.3 8) strains. The same result as CAMP-factor Ic was observed in 9 (6 8) strains, and exosubstances of $11(7.3$ 8) strains reacted like CAMP-factor of the strain III. Three ( 28 ) strains reacted simultaneously with CAMP-factor antisera. III and $X$, and $7(4.68)$ with antisera III and $R$. The same result as with the strain $X$ was gained with 29 (19.3 8) strains, and as with the strain $R$ with 36 (24 8) strains. Thirteen 
Table 1

serotyping of $\mathrm{s}$. agalactiae strains by means of the BO-test

\begin{tabular}{|c|cc|}
\hline $\begin{array}{c}\text { Antisera against } \\
\text { CAMP-factors of } \\
\text { S. agalactiae } \\
\text { serotype strains }\end{array}$ & $\begin{array}{c}\text { Number of positively reacting } \\
\text { S. agalactiae strains from }\end{array}$ \\
\hline Ia & & \\
Ib & 9 & 2 \\
Ib + Ic & 7 & 5 \\
Ic & 3 & 2 \\
II & 28 & 9 \\
III & 15 & 4 \\
III + X +29 & 3 \\
X & 0 & 7 \\
X + R & 14 & 29 \\
R & 3 & 13 \\
B & 2 & 36 \\
not alloted & 17 & 2 \\
\hline total & 4 & 27 \\
\hline
\end{tabular}

(8.6 8 ) strains precipitated both with CAMP-factor antisera X and R. Two (1.3 \&) strains only reacted with CAMP-factor antiserum B. No allotment was possible for 27 (18 8) strains displaying reactions with all CAMP-factors antisera but forming only the second and third precipitation lines (Table 1).

Streptococcal strains of other serological groups than the group B which were used for checking gave results with all CAMP-factor antisera.

The commercial antiserum for identification of group B streptococci, used for controlling purposes in this study, gave no positive precipitation with both prepurified and native CAMP-factors.

\section{Discussion}

The availability of CAMP-factor for identifying of $S$. agalactiae is undeniable. Its production can be determined by means of the original technique for hemolytic synergism with staphylococcal beta toxin (C h r i s t i e et al. 1944) or with the corynebacterial phospholipase $D(S \mathrm{k} / \mathrm{k}$ a et al. 1979). The employment of this phenomenon caused studies on the nature of synergistic hemolytic interaction ( $K$ a $r$ C ho u d r y 1978; B e r h e i mer et al. 1979).

The up to date scarce studies concerning antigenic properties of the CAMP-factor claimed the presence of neutralizing antibodies in blood sera - though as a rule in low titres - following experimental and spontaneous infections by $S$. agalactiae ( $B$ r o w et al. 1974; F lor e s and Fer r e r i 1983). Our experience failed to confirm such type of CAMP-factor antibodies, even in the rabbit antisera evidently containing precipitins, but we noted the neutralizing activity in normal sera of rabbits, cattle and humans, up to the dilution $1 / 60$ ( $\mathrm{S} \mathrm{k} \mathrm{a} 1 \mathrm{k}$ a et al. 1980; Ska lka and S mola 1981).

Little attention has been payed to the problem whether CAMP-factors produced by different strains of group B streptococci are of identical different antigenicity. Antigenic identity of CAMP-factors was described by F $1 \circ \mathrm{r} \in \mathrm{s}$ and F e r r i r i (1983), nevertheless, the authors investigated only the strains belonging to the serotype III.

Our results confirmed and employfied this observation. They rendered evidence that CAMP-factors produced by different strains of $S$. agalactial contained identical or common antigenic fraction(s) arising precipitation lines referred to as second and 
third, as well as an antigenic fraction giving the precipitation line referred to as tirst which can be considered as specific for some clumps of $S$. agalactiae strains. The antigenic relation between CAMP-factor and the serotyp pertinence of producer strain is utmost remarkable.

Admittedly, the prepurified CAMP-factor could contain some traces of soluble cellular antigenic substances, neither can be excluded the contamination of native CAMP-factor with such ones, but the negative precipitation of both prepurified and native CAMP-factors with the commercial antiserum makes the importance of such eventuality insignificant.

\section{Antigenní diferenciace CAMP-faktorũ produkovaných rúznými kmeny Streptococcus agalactiae}

V rámci druhu Streptococcus agalactiae byl zjištován antigenní vztah mezi CAMP-faktory produkovanými reprezentativními kmeny jednotlivých sérotypú, a to Ia, Ib, Ic, II, III, X a $R$, a kmeny Cerstvě izolovanými z biologických materiálú. Separované formy CAMP-faktorú typových kmenú byly použity $k$ intravenózním aplikacím králíkúm, ze kterých se získala antiséra. Pro antigenní určování byla použita dvojitá agarová imunodifuze s prepurifikovanými CAMP-faktory jako antigeny a modifikovaný Elek-Ouchterlonyho test, využívající nativní formu této exosubstance jako antigen. V reakcích korespondujícího antigenu a jeho antiséra vznikaly tři linie precipitátu. První z nich se pozorovala pouze $v$ homologních pŕípadech, druhé dvě vznikaly $v$ testech homologních i heterolognich. To prokázalo existenci spoležné a specifické antigenní frakce v CAMP-faktorech. Pro vyšetření 300 kmenù $S$. agalactiae byl použit jen modifikovaný Elek-Ouchterlonyho test, nevyžadující speciální přípravu antigenu. Kmeny byly hodnoceny na podkladĕ podobnosti reakce jejich CAMP-faktorú s reakcemi CAMP-faktorú typových kmenú. Ze 150 kmenú humánní provenience by!a tato podobnost nejčastěji s reakcemi CAMP-faktorú typú Ic a III, ze 150 kmenú $z$ mléxné žlázy skotu dával největš̌i pơ̌et kmenư reakce podobné CAMP-faktorưm typů $X$ a $R$.

Антигенная дифференциация САМР факторов, продуцированных разными штаммами Streptococcus agalactiae

В рамках вида Streptococcus agalactiae определялись антигенные отношения между САМР-фахторами, продуцированными представительными штаммами отдельных серотипов, а именно $1 \mathrm{a}, 1 \mathrm{~b}, 1 \mathrm{c}, \mathrm{n}, \mathrm{I}, \mathrm{X}$ и $\mathrm{R}$, и штаммами, изолированными из биологических материалов. Сепарирожанные формы САМР-фахторов типовых штаммов были внутривенно использованы у хроликов, от хоторых были получены антисывопотки. Для антигенного определения была использована двойная агаровая иммунодиффузия с заранее очищенными САмП-фахторами в хачестве антигенов и модифицированный тест по Элех-Уштерлони, используюший естественную форму данной экзосубстанции в качестве антигена. В реакииях цоответитвуюшего антигена и его антисыворотхи вознихали три линии преципитата. Первая из них встречалась лишь в гомологичных случаях, следующие две линии вознихали в гомологичных и инадехватных случаях. Это стало дохазательством сушествования совместной и специфической антигенной фрахции в САмП-фахторах. Для исследования 300 штаммов S. agalactiae был использован только тест по Элех-Уштерлони, не требующий специальной подготовки антигена. Оценка штаммов проводилась а основе подобия реакции их САмП-факторов с реакииями САмП-факторов типовьх штаммов. Из 150 штаммов человека данное подобие чаще вцего встречали с реакииями САмП-фахторов типов 1с и $\mathrm{m}$, из 150 штаммов молочной железы хрупного рогатого скота самое больтое число ттаммов по своей пеакции были похожи на САмП-фахторы типов X и $R$.

\section{References}

BERNHEIMER, A.W. - LINDER, R. - AVIGAD, L.S.: Nature and mechanism of action of the CAMP protein of group B streptococc1. Infect. Immunity, 23, 1979, 838-844. 
BROWN, J. - FARNSWORTH, R. - WANNAMAKER, L.W. - JOHNSON, D.W.: CAMP-factor of group B streptococc1: production, assay, and neutralization by sera from immunized rabbits and experimentally infected cows. Infect. Immunity, 9, 1974, 377-383.

CHRISTIE, R. - ATKINS, N.E. - MUNCH-PETERSEN, E.: A note on a lytic phenomenon shown by group B streptococc1. Austral. J. Exp. B1ol. Med., 22, 1944, 197-200.

ELEK, S.: The recognition of toxinogenic bacterial strains in vitro. Brit. Med. J., I, $1948,493-496$.

FLORES, E.A. - FERRIERI, P.: Blochemical markers of the penicilin induced $L$ phase of a group B, type III Streptococcus sp. J. Clin. Microbiol., 18, 1983, 961-967.

FRASER, G.: The effect on animal erythrocytes of combinations of diffusible sustances produced by bacteria. J. Pathol. Bacteriol., 88, 1964, 43-53.

HENRICHSEN, J. - FERRIERI, P. - JELINKOVA, J. - KOHLER, W. - MAXTED, W.R.: Nomenclature of antigens of group B streptococc1. Int. J. Syst. Bacteriol., 34, 1984, 500 .

JELINKOVA, J.: Streptokoky skupiny B. 166-172 (a). In: ROTTA, J.: Patogenní streptokoky. Avicenum 1983, Praha, 258 p.

JELINKOVA, J.: Typizace streptokokủ skupiny B. 224-226 (b). In: ROTTA, J.: Patogenní streptokoky. Avicenum 1983, Praha, 258 p.

KAR CHOUDRY, T.K.: Synergistic lysis of erythrocytes by Propionibacterium acnes. J. Clin. Microblol., 8, 1978, 238-241.

LANCEFIELD, R.C.: A serological differenctation of human and other groups of hemolytic streptococc1. J. Exp. Med., 57, 1933, 571-595.

LANCEFIELD, R.C.: A serological differentiation of specific types of bovine hemolytic streptococc1 (group B). J. Exp. Med., 59, 1934, 441-458.

OUCHTERLONY, $0 .:$ In vitro method for testing the toxin-producing capacity of diphtheria bacter1a. Acta Pathol. Microb1ol. Scand., 25, 1948, 186-191.

PATTISON, I.H. - MATTHEWS, P.R.J. - MAXSTED, W.R.: The type classification of group B streptococc1, with special reference to bovine strains apparently lacking in type polysaccharide. J. Pathol. Bacteriol., 69, 1955, 43-50.

PHILLIPS, E.A. - TAPSALL, J.W. - SMITH, D.D.: Rap1d tube CAMP-test for Identification of Streptococcus agalactlae (Lancefield group B). J. Clin. Microbiol., 12, 1980, 135-137.

PULSFOKD, M.F.: Some factors influencing the production of CAMP factor by Streptococcus agalactlae. Austral. J. Exp. Biol. Med., 32, 1954, 353-360.

SKALKA, B. - SMOLA, J.: Lethal effect of CAMP-factor and UBERIS-factor - a new finding about diffusible exosubstances of Streptococcus agalactiae and Streptococcus uberis. Zbl. Bakt. Hyg., I. Abt. Or1g. A 249,1981, 190-194.

SKALKA, B. - SMOLA, J. - PILLICH, J.: Diagnostic utilization of hemolytically active exosubstance of certain Gran positive bacteria. I. Detection od staphylococcal hemolysins with prepurified preparations of staphylococcal beta toxin and CAMP-factor of Streptococcus agalact1ae. J. Hyg. Epidem1ol. Microb1ol. Immunol. (Prague), 23,1979 a , 407-416.

SKALKA, B. - SKOLA, J. - PTLLICH, J.: Diagnostical ava1lability of the hemolytically active exosubstance of Corynebacterium pseudotuberculosis for 18olation and Identification of Streptococcus agalactiae and 1 ts comparison with the beta toxin of Staphylococcus aureus. Zb1. Vet. Med. B, 26, 1979 b, 679-687.

SKALKA, B. - SMOLA, J. - PTLLICH, J.: Comparison of some properties of the CAMP-factor from Streptococcus agalactiae with the haemolytically latent active exosubstance from Streptococcus uber1s. Zbl. Vet. Med., B, 27, 1980, 559-566.

SKALKA, B. - ŠASTOVA, A.: Serodiagnost1c of Corynebacterium (Rhodococcus) equi. Zbl. Vet. Med. B, 32, 1985, 137-142.

SOUREK, J.: Catalogue of pathogenic microorgan1sm. Inst. Hyg. Ep1dem1o1., 1981, Prague, $216 \mathrm{p}$.

WILKINSON, H.W. - MOODY, M.D.: Serological relationships of type I ant1gens of group B streptococc1, J. Bacteriol., 97, 1969, 629-634. 